\title{
Reflections on the concept of leadership: shared leadership in the EU and the euro crisis*
}

\author{
Isabel Camisão \\ NICPRI [Universidade do Minho]; and Universidade de Coimbra, Portugal
}

\begin{abstract}
Summary: I. Introductory remarks.-II. Reviewing the concept of leadership. 1. Defining leadership: an impossible task? 2. The singularity of EU shared leadership.-III. Leadership through the lens of European Integration Theories. - IV. The quest for good leadership: the importance of ethics and effectiveness and how it applies to the EU case. - V. Assessing EU leadership in the euro crisis: pragmatic, directional, or both? 1. The context: the need for reform. 2. The pragmatic dimension of leadership: strategy and measures for tackling the crisis in the short/medium term. 3. The directional dimension: a design and an integrated vision for the long-time. 4. The Franco-German tandem: a new balance of power or a matter of perception? - VI. Concluding remarks: European leadership beyond the Euro crisis.
\end{abstract}

\begin{abstract}
The EU is experiencing probably the lowest level of public support in its history. Proper political leadership is crucial to the success or failure of political entities, especially in times of crisis. Periods of crisis represent dangers, but may also represent the opportunity to reform the EU governance and its policies. This will require leaders who are able to balance pragmatic and directional leadership. This article thoroughly reviews the concept of leadership. It then focuses on the challenges presented by the singularity of the European shared leadership, concluding with a note on the importance of "adequate" leaders and timely political leadership for tackling the present Euro crisis and guaranteeing the future of the European project.
\end{abstract}

Keywords: European Union, leadership, crisis, reform.

Resumen: La UE registra actualmente uno de los niveles más bajos de apoyo popular de su historia. Un liderazgo político adecuado resulta determinante en el éxito o el fracaso de los entes políticos, especialmente en tiempos de crisis. Los períodos de crisis representan peligros, pero también una oportunidad de reformar la gobernanza y las políticas públicas europeas. La consecución de este objetivo precisará líderes capaces de equilibrar un liderazgo pragmático con un liderazgo orientador. Este artículo explora en detalle el concepto de liderazgo para, a continuación, centrarse en los desafios que plantea la singular característica del «li-

* Recibido 9 de mayo de 2012, aceptado el 5 de junio de 2012. 
derazgo compartido» en la UE. A modo de conclusión, se apunta la importancia, para resolver la crisis actual y garantizar el futuro del proyecto europeo, de contar con unos líderes «adecuados» dispuestos a ejercer auténtico liderazgo político en tiempo útil.

Palabras claves: Unión Europea, liderazgo, crisis, reforma.

\section{Introductory remarks ${ }^{1}$}

In recent years, the effects of the economic crisis have amplified the so-called European "leadership crisis". The call for "leadership" makes the headlines of the European press. Both academics and former European leaders have been pointing their fingers to what they see as a leaderless Europe $^{2}$. In fact, there is a widespread perception among European citizens that Europe lacks effective leaders to cope with the economic crisis but mostly to develop a new plan for the future. Leadership, or at least competent and timely leadership, has long been recognized as crucial for human achievement and well-being ${ }^{3}$. A good leader must be able to correctly analyse the situation and make informed decisions, while preserving the core values of the group. This is a particularly difficult task in times of crisis.

Crises are harmful and disruptive events for the organizations (and for the political systems). There is a variety of acute events that could be classified as crisis - international confrontations, acts of terrorism, natural disasters, severe economic or financial breakdowns, environmental threats, among others - but generally they all share certain key characteristics: severe threat, high uncertainty, and time pressure ${ }^{4}$. Crises are therefore unexpected, dramatic, of great magnitude, and require timely response ${ }^{5}$. Thus,

1 The present work is part of an on-going post-doctoral research sponsored by the Portuguese Foundation for Science and Technology (Fundação para a Ciência e a Tecnologia).

2 In a letter published in The Guardian, eighteen reputed academics and former European leaders (including Jurgen Habermas, Giuliano Amato, and Alfred Gusenbauer) call on current Europe's leaders "to take over the political agenda again and develop a new plan for the future of a prosperous and united eurozone". And they go on arguing: "We are concerned about the current state of EU politics and the long-term damage it could cause". Accessed at http://www.guardian.co.uk (12.01.2012). By the same token, Helmut Schmidt, in an interview published in the MarketWatch (Dec. 7, 2010) explicitly states: “... in general, Europe lacks leaders. It lacks people in high positions in the national states or in the European institutions with sufficient overview of domestic and international questions and sufficient power of judgment". Accessed at http://www.marketwatch.com (17.01.2012).

${ }^{3}$ GILL, R., Theory and Practice of Leadership, $2^{\text {nd }}$ ed., ed. Sage, London 2011, p. 1.

4 't HART, P., ROSENTHAL, U. and KOUZMIN, A., "Crisis Decision-making: The Centralization Thesis Revisited”, in Administration \& Society, 25 (1), 1993, p. 13.

5 BASS, B.M. with BASS, R., The Bass Handbook of Leadership: Theory Research and Managerial Applications. $4^{\text {th }}$ ed. Free Press, New York 2008, p. 837. 
serious threats cannot be dealt with in routine operations ${ }^{6}$. Crisis implies the adaptation of the structure and culture of an organization or a polity. An example of such adaptation "would be the centralization of decision-making"7 i.e., the concentration of power in the hands of a limited number of persons. Also, this adaptation may relate to the tendency to look for strong leadership. This explains why charismatic leadership tends to arise in times of crisis.

In effect, in troubled times leaders are expected to make decisions in unprecedented circumstances. Modern crises reflect the interdependency and interconnection of today's world, meaning that they can rapidly escalate and become systemic. Therefore, they should be treated "as extended periods of high threat, high uncertainty, and high politics that disrupt a wide range of social, political and organizational processes" ${ }^{8}$. This seems to be the case of the on-going economic and financial crisis. Today's leaders need to be well prepared and to expect the unexpected, because leadership in modern crises is an extremely difficult undertaking. Citizens are wary of crises, but most of the times they do not fully understand their intricacies. In the present crisis, citizens suffer directly its impact, i.e., they experience the immense costs and penalizations in their daily life; this contributes to a drastic decline in public trust in the capacity of state (and of political leaders) to perform their classic functions, namely, to protect its constituencies. As crises become more complex, more politically salient, and more expanded in scope, the stakes for political leaders are raised ${ }^{9}$. Policy makers need to establish that they are not responsible for the crisis, and they ought to be able to take effective measures to protect the public, limit negative effects, and compensate damages ${ }^{10}$.

Besides, leaders need to effectively communicate with their citizens. Communication, however, is a two-way process, i.e. the leader must have the capacity to communicate and explain his vision and strategy but also the capacity to incorporate in it the perceived needs of the followers. This could prove to be extremely difficult when people do not easily understand who leads, or do not recognize the positional leaders the legitimacy to lead, as appears to be the present case of the European Union (EU). Some authors even refer to a "crisis in followership", since "in the political world, leaders appear to have fewer and fewer followers" 11 . It is however "the popular

6 Vid. 't HART, P., ROSENTHAL, U. and KOUZMIN, A., op. cit., nota 4, p. 13.

7 Ibid., p. 13.

${ }^{8}$ BOIN, A., and 't HART, P., "Public Leadership in Times of Crisis: Mission Impossible?". Public Administration Review, September/October 2003, Vol. 63, N. ㅇ 5, 2003, p. 545.

${ }^{9}$ Ibid., p. 544.

${ }_{10}$ Ibid., p. 546.

11 Vid. GILL, R., op. cit., nota 3, p. 12. 
perception of authority and assertiveness which largely accounts for what is meant by political leadership or the absence of it" ${ }^{12}$. Briefly, as Boin and 't Hart assert, "crisis management has never been easy [but] leadership in the face of this sort of adversity is... precarious"13. However, the authors do acknowledge that "whether they like or not, crisis management has become a leadership issue" 14 .

Does a crisis provide the ideal opportunity to reform institutions and policies? Boin and 't Hart, in particular, are very sceptical towards the "popular notion" that crisis provides key opportunities for reform. According to them, reform leadership requires overcoming the numerous barriers to institutional change in policy-making, which could become a "daunting task"15. In order to successfully "sell" the novel policy ideas and to surpass the resistance in societal, political and bureaucratic arenas, reform leaders must convince the "audiences" "that the status quo is untenable, propose a coherent set of radical and politically sanctioned reforms, and guard their integrity during reform implementation" 16 . Thus, they go on claiming that reform leadership is based on persuasion and could only be feasible if the reform leader is not to blame for the crisis at hand, and if he or she communicates effectively his/ her personal commitment to reform: "Moreover, they must convince stakeholders that the benefits of the proposed reform outweigh the sunk costs of existing structures and policies"17. Additionally, it is important to stress that after the reform package being accepted it still needs to be implemented, a process that could turns out to be even more problematic than the agreement on the set of reforms. These difficulties become even harsher in a sui generis political system like the EU, based on a shared model of leadership.

The hybrid nature of the EU and the consequent necessity to accommodate in a single model the supranational and intergovernmental traits of the European construction hinder the understanding of European leadership's intricacies. The EU has a unique power-sharing mechanism between European institutions, though the states still retain great leverage to determine the path of European integration. Also, Europe has a distinctive culture of "consensus-building", which in several times has proven essential to grasp agreement in European negotiations ${ }^{18}$. There is, therefore, a "dispersal of

12 CRAMME, O., "In Search of Leadership", 2010, p. 30. Accessed at http://www2.1se. ac.uk/europeanInstitute/events/2010-11/articles/EILSOlafCramme.pdf (12.09.2011).

13 Vid. BOIN, A. and 't HART, P., op. cit., nota 7, p. 545.

14 Ibid., p. 546.

15 Ibid., p. 549.

16 Ibid., p. 549.

17 Ibid., p. 550.

18 Vid. CRAMME, O., op. cit., nota, 12, p. 33. 
leadership potential" 19 which was not resolved by the last institutional reform. In fact, at least at first sight, the new institutional set-up introduced by the Lisbon Treaty seems to add complexity to the already complex puzzle of European leadership.

The above-mentioned problem is directly related with the issue of political accountability, i.e. the need to have visible leaders, and procedures that legitimize decisions and actions in the perception of European citizens. The constituencies should be able to identify who is responsible for a certain decision and who can be held accountable for the EU's action or inaction ${ }^{20}$. But, arguably, from the citizens' point of view, the problem with European leadership is not only a question of understanding who leads the EU; it is also a question of leadership effectiveness. Evaluating leadership effectiveness in a political entity like de EU is not simply synonymous of measuring its economic impact. It is rather a question of assessing the leader's capacity for successfully choosing the means that bring about the desired ends, while preserving the key-values that have supported European integration over the years. If to instrumental efficacy we add an ethical dimension, the effectiveness of leadership becomes "determined by the actual short- and long- term consequences of a leader's actions" ${ }^{21}$. These are the two interrelated senses of what some scholars called "good leadership"22.

\section{Reviewing the concept of leadership}

\section{Defining leadership: an impossible task?}

According to Bernard Bass ${ }^{23}$ leadership "makes the difference". There are, of course, theses that undervalue the importance of leadership ${ }^{24}$. Some

19 Ibid., p. 35.

20 BERTELSMANN FOUNDATION AND CENTER FOR APPLIED POLICY RESEARCH, (eds.), "Bridging the Leadership Gap. A Strategy for Improving Political Leadership in the EU by the Thinking Enlarged Group", 2002, p. 2. Accessed at http://www. emmanouilidis.eu/download/2002_leadership_gap.pdf (15.01.2012).

${ }^{21}$ MASCIULLI, J., MOLCHANOV, M.A. and KNIGHT, W.A., "Political Leadership in Context", in MASCIULLI, J., MOLCHANOV, M.A. and KNIGHT, W.A. (eds.), The Ashgate Research Companion to Political Leadership, ed. Ashgate Publishing, Farnham Surrey 2009, p. 10.

22 CIULLA, J.B., "What is good Leadership". Working Paper, Center for Public Leadership 2004. Accessed at http://dspace.mit.edu/bitstream/handle/1721.1/55929/CPL_ WP_04_07_Ciulla.pdf?sequence=1 (25.09.2011).

${ }_{23}$ Vid. BASS, B.M. with BASS, R., op. cit., nota 5, p. 3.

${ }^{24}$ See for exemple, PANDLEY, J., "Effects of leadership style, personality characteristics and methods of leader selection on members' leaders' behaviour", in European Journal of 
extreme critics contend "all the effects of leadership are a romantic fiction, existing only in the eye of the beholder" 25 . Others simply do not recognize the usefulness of the concept of leadership for understanding social influence $^{26}$. Roger Gill ${ }^{27}$ argues that the lack of consensus on what leadership is together with some practices dubiously identified as leadership have contributed to a cynical vision about the importance of leadership. However, the majority of the researchers agree that leadership, or at least good leadership, is one critical factor in the success or failure of organizations and of political entities ${ }^{28}$.

Doubtless, leadership has become a key issue, both in public and private sphere; it is, in Gill's words ${ }^{29}$, a "hot topic for debate". But, what is leadership? There are countless definitions of leadership that have been evolving and expanding over the years ${ }^{30}$. The literature on leadership varies along a spectrum that ranges from very detailed prescriptive fixes on how to become an "outstanding" leader to highly theoretical and complex models. The specialists tend to agree that the definition of leadership should depend on the purposes to be served, meaning that one could "adapt" the concept's definition to the purpose of the study ${ }^{31}$. Accordingly, leadership has been defined in terms of individual traits, characteristics, skills, competences, as well as a process, a power relation, an exercise of influence, a construct, among many others. Besides, leadership research has gradually become multidisciplinary ${ }^{32}$, consequently suffering "from a lack of common language" 33 . Despite the great variety of definitions, as Bass maintains, "the definitions indicate a progress of thought" 34 . While the first definitions were essentially "leadercentric", the more recent definitions:

"conceive leadership in terms of influence relationships, power differentials, persuasion, influence on goal achievement, role differentia-

Social Psychology, 6, 1976, pp. 475-489; MEINDL, J.R.; EHRLICH, S.B. and DUKERICH, J.M., "The romance of leadership", in Administrative Science Quarterly, 30, 1985, pp. 78-102.

25 Vid. BASS, B.M. with BASS, R., op. cit., nota 5, p. 9.

26 Ibid., p. 9.

27 Vid. GILL, R., op. cit., nota 3, p. 1.

28 Vid. BASS, B.M. with BASS, R., op. cit., nota 5, p. 10.

29 Vid. GILL, R., op. cit., nota 3, p. 2.

30 See, for example, BASS, B.M. with BASS, R., The Handbook of Leadership: Theory, Research, and Managerial Applications. 4th ed., ed. Free Press, New York 2008, pp. 15-26; GILL, R., Theory and Practice of Leadership. 2nd ed., ed. Sage, London 2011, pp. 2-11.

31 Vid. BASS, B.M. with BASS, R., op. cit., nota 5, p. 25.

32 Modern leadership studies draw on insights from several scientific areas, such as psychology, sociology, political science, history, organizational theory, among others.

33 TERRY, R. Vid. GILL, R., op. cit., nota 3, p. 3.

34 Vid. BASS, B.M. with BASS, R., op. cit., nota 5, p. 24. 
tion, reinforcement, initiation of structure, and perceived attributions of behaviour that are consistent with what the perceivers believe leadership to be" 35 .

Let's now look to some of the most well known definitions of leadership. James Macgregor Burns argues that leadership "over human beings is exercised when persons with certain motives and purposes mobilize, in competition or conflict with others, institutional, political psychological, and other resources so as to arouse, engage and satisfy the motives of followers" 36 . Therefore, he defines leadership "as leaders inducing followers to act for certain goals that represent the values and the motivations - the wants and the needs, the aspirations and expectations - of both the leaders and followers" 37 [italics in the original]. Peter Northouse sees leadership as "a process in which an individual influences a group of individuals to achieve a common goal" 38 . For Joseph Nye, leadership "is a social relation with three key components - leaders, followers, and the context in which they interact" 39 . Joanne Ciulla makes the point that "Leadership is largely a social construction based on the values and events of the times. The idea of a leader is shaped by what people in a culture think a leader ought to be"40. Masciulli, Molchanov and Knight, referring to political leadership wrote: "Leadership is an essential feature of all government and governance ... The lack of leadership routinizes governance. Its political and creative aspects fade way: it becomes no different from administration, focusing solely on pattern maintenance and repletion of the same"41.

Leadership is therefore a "transversal concept" 42 , meaning that the word is used as an "umbrella" for multiple meanings, dimensions and practices. Outside the academic or practitioner world, the definitions of leadership tend to be even more inclusive. As J. Richard Hackman notes "the popular press ... frequently refers to the 'leadership' that is provided by a charismatic orator, a clever financier, or even a brilliant scientist" ${ }^{\text {"43. How- }}$

35 Ibid., p. 24.

36 BURNS, J.M., Leadership, ed. Harperperennial Political Classics, New York 2010, p. 18.

37 Ibid., p. 10.

38 Vid. BASS, B.M. with BASS, R., op. cit., nota 5, p. 21.

39 NYE jr., J.S., The Powers to Lead, ed. Oxford University Press, Oxford 2008, p. xviii.

40 Vid. CIULLA, J.B., op. cit., nota 22, p. 116.

41 Vid. MASCIULLI, J., MOLCHANOV, M.A. and KNIGHT, W.A., op. cit., nota 21, p. 4.

42 Vid. CRAMME, O., op. cit., nota 12, p. 33.

43 HACKMAN, J.R., "What is this Thing Called Leadership?", in NOHRIA, N. and KHURANA, R. (eds.), Handbook of Leadership Theory and Practice, Harvard Business Press, Boston MA, 2010, p. 108. 
ever, as the author asserts, too much inclusiveness could hobble research on the topic ${ }^{44}$.

Despite the plethora of definitions, it is possible to highlight some important features that are common to several of the most recent definitions of leadership: it is an interactive two-way process between a leader and a follower; this interaction involves structuring or restructuring a situation and the perceptions and expectations of the followers; leaders are agents of change; leaders influence the group and direct the attention of other members to goals and the paths to achieve them ${ }^{45}$. By looking at a vast group of leadership definitions, Ciulla argues that the definitions of leadership adopted by scholars tend to "generally say the same thing - leadership is about a person or persons somehow moving other people to do something" 46 . These definitions do differ, however, in at least four aspects: "how leaders motivate their followers, their relationship to followers, who has a say in the goals of the group or organization, and what abilities the leader needs to have to get things done" 47 .

In brief, I endorse Gill's argument that to understand leadership it is important to look to the etymology of the word and how its meaning has evolved ${ }^{48}$. Thus, he claims, the essence of leadership is "showing the way and helping or inducing others to pursue it. This entails envisioning a desirable future, promoting a clear purpose or mission, supportive values and intelligent strategies, and empowering and engaging all those concerned"49. Drawing on Gill's model of leadership, I propose that political leadership should entail both a pragmatic dimension and a directional one. The former is mainly related to the capacity of designing and implementing an adequate strategy to tackle the (more immediate) problems and attain the envisioned outcomes; also it entails an adequate understanding of the context and circumstances, and an accurate identification of threats and opportunities. The second is mostly related with the capacity to set a shared vision for the future, one that is served by the pragmatic moves taken in the short/medium term.

${ }^{44}$ Ibid., p. 108.

45 Vid. BASS, B.M. with BASS, R., op. cit., nota 5, pp. 23-25.

${ }^{46}$ CIULLA, J.B., "Ethics and Leadership Effectiveness", p. 306. Accessed at http:// strandtheory.org/images/Ciulla_-_Ethics_and_Leadership_Effectiveness.pdf (25.09.2011).

${ }^{47}$ Ibid., p. 306.

48 Vid. GILL, R., op. cit., nota 3, p. 8.

49 Ibid., p. 9. 


\section{The singularity of EU's "shared" leadership}

On the word of Wolfgang Wessels there is a factual demand for leadership, especially in such a huge and heterogeneous group like the $\mathrm{EU}^{50}$. Consequently, he contends that more attention should be paid by the academics to the issue of leadership. However, analyzing leadership in a European Union of twenty-seven (almost twenty-eight) member states is an extremely complex task. Despite the recognized major contribution of a handful of inspiring figures - such as Jean Monnet, Paul Henri-Spaak, Alcide De Gasperi, and more recently Helmut Kohl, François Mitterrand or Jacques Delors - the reality is that the European integration process is mostly a result of "consensus-building". Many of the EU's important leaps were grasped through long and sometimes hardworking negotiations. Therefore, talking about political leadership in the EU is talking about "individual and institutional actors who interact in the quest for a mutually beneficial result during a process of collective choice" ${ }^{\prime \prime}$. The hybrid nature of the $\mathrm{EU}$, created for encompassing both intergovernmental and supranational traits, results in a diversity of stakeholders: "In the EU, various supranational institutions share power with the member states: the lines of authority are mostly horizontal rather than pyramidal. There is no single institution clearly in charge and able to give orders to the rest of the organization" 52 .

The EU model rests on a "purposeful diffusion of political authority between supranational and intergovernmental institutions" 53 , thus being based on the principle of shared leadership. Furthermore, enlargement and the continuous deepening of integration lead to changes in the structural patterns of the European polity, which have emphasized the bargaining dimension of the EU decision-making process. In today's EU the power is diffused among a growing number of "supposedly equal partners" 54 - the national leaders - and institutional headships, making extremely hard for the citizens to identify who truly leads and consequently to really connect with that person or persons. The difficulties of exerting "personality politics" in

${ }^{50}$ LISBOAN WORKING GROUP (Report), Workpackage II "Integration Theory and Governance after Lisbon”, June 2011, Accessed at: http://typo3-8442.rrz.uni-koeln.de/ fileadmin/wiso_fak/europ_pol/doc/Conference_2011_Reports/Report_WG_II_Integration_ Theory_and_Governance_Mueller.pdf (15.05.2012).

51 Vid. CRAMME, O., op. cit., nota 12, p. 33.

52 GUEROT, U., "Political Leadership for the European Union", p. 1. Accessed at http:// www.epin.org/new/files/06_Guerot_leadership.pdf (25.09.2011).

53 BUNSE, S., MAGNETTE, P. and NICOLAIDIS, K., "Shared Leadership in the EU: Theory and Reality" 2005, p. 1. Accessed at www.sant.ox.ac.uk/people/knicolaidis/asser.doc (21.04.2011).

54 Vid. CRAMME, O., op. cit., nota 12, p. 35. 
the European polity are obvious and are further complicated by the absence of genuine EU-media coverage and by language barriers ${ }^{55}$.

The new institutional-set introduced by the Lisbon Treaty does not countervail those constraints. In fact, it maintains the dispersal of leadership potential and power in the EU, contributing to the perceived "babel" of European leadership. To the President of the European Commission, the Treaty adds the elected semi-permanent President of the European Council. Besides this tandem, institutionally we have to consider the eighteenmonths trio-presidency, the High Representative (simultaneously High Representative for Foreign and Security Policy and Vice-President of the Commission), the President of the European Parliament, the President of the Euro group, and the President of the European Central Bank. This plethora of (institutional positional) leaders is further complicated by the possibility of national leadership coalitions, composed by a changeable number out of the 27 national leaders (that are often more concentrated in national interests rather than in the "common good"). Also, as stressed above, leadership is by no means strictly dependent on formal power.

In short, analyzing leadership in the UE is therefore analyzing a process, in which different individuals, institutions, or governments (or a combination of those) could have the resources to influence others in the bargaining process, therefore assuming a leadership role. Plus, the answer to the question "who leads in the EU?" is also very much dependent on the context and on the type of issue on the agenda. For instance some authors argue that in diplomatic issues France generally takes the lead, whereas in economic and monetary affairs this role is normally performed by Germany ${ }^{56}$. In addition, it should be stressed that leading negotiations at the EU level does not automatically means that European citizens recognize that person and/or institution the legitimacy to lead.

\section{Leadership through the lens of European Integration Theories}

In a highly complex polity like the EU, the concept of political leadership is, as already affirmed, extremely difficult to grasp. Being a multi-level system that encompasses different levels and a multitude of actors, the EU provides diverse opportunities and demands for political leadership. It is,

55 Ibid., p. 35.

56 SCHILD, J., vid. LISBOAN WORKING GROUP (Report), Workpackage II "Integration Theory and Governance after Lisbon", June 2011, Accessed at: http://typo3-8442.rrz. uni-koeln.de/fileadmin/wiso_fak/europ_pol/doc/Conference_2011_Reports/Report_WG_II_ Integration_Theory_and_Governance_Mueller.pdf (15.05.2012). 
however, a type of leadership, which in terms of results, duration, manifestations and sources of legitimacy could be fundamentally distinct from national leadership ${ }^{57}$.

Integration theory has, for the most part, neglected the issue of leadership. Notwithstanding, even if in a residual way, the various perspectives on the integration process highlight different accounts on leadership. Traditionally, leadership in the Community was seen as being either structural (deriving primarily from the so-called supranational institutions) or associated with particular individual figures, which have the charisma and the positional power to lead. Such figures could be national figures (such as Charles de Gaulle) or "supranational" figures (like Jean Monnet, Walter Hallstein, or Jacques Delors) ${ }^{58}$.

The first comprehensive theory of European Integration was Ernst Haas' Neo-functionalism, developed in the 1960's. In his classic work on the European Coal and Steel Community, Haas defined integration as "the process whereby political actors in several distinct national settings are persuaded to shift their loyalties, expectation and political activities to a new center whose institutions possess or demand jurisdiction over the pre-existing national states" 59 .

Building on David Mitrany and Jean Monnet's functionalism, Haas attributed a decisive role to the supranational institutions, particularly to the independent European Commission ${ }^{60}$. In his view, the Commission in the exercise of its powers (namely as guardian of the treaties and as having the monopoly of legislative initiative) would formulate and implement a sufficient amount of legislative policies, which in turn would contribute to a shift of attention and loyalties from the national to the supranational level. The functional spill-over would then occur, furthering the European integration. The neo-functionalist approach was, afterwards, developed by Leon Lindberg. In his study of the early EEC, ${ }^{61}$, Lindberg was rather more cautious in his vision of integration, which was defined without reference to an end point. The emphasis was put in "the development of devices and processes for arriving at collective decisions

${ }^{57}$ DRAKE, H., "Political Leadership and European Integration: The Case of Jacques Delors", Paper deliver to the Third Biennial Conference of the European Community Studies Association, Washington DC, May, 27-29, 1993, p. 2.

58 Ibid., p. 2.

59 HAAS, E., The Uniting of Europe: Political, Social and Economic Forces 1950-1957, ed. Stanford University Press, Standford, 1958, p. 16.

${ }^{60}$ In the European Coal and Steel Community the equivalent to the European Commission was called High Authority.

${ }^{61}$ LINDBERG, L., The Political Dynamics of European Economic Integration, ed. Standford University Press, Standford, 1963. 
by means other than autonomous action by national governments"62. Therefore, for the early neo-functionalists, political leadership was supposed to be primarily structural, largely emanating from a supranational institution - the Commission.

The crisis experienced by the European integration process in the mid1960 s, cast doubts on the deterministic view of the process initially maintained by Haas's theory. The critics included Haas himself, who then admitted that he had not foreseen "a rebirth of nationalism and anti-functional high politics" 63 . This unexpected turn in the European integration theory was triggered by Charles de Gaulle, whose actions ${ }^{64}$ were aimed at repossessing the decision-making stages for national leaders and their governments. As a result, the Commission's credibility was seriously jeopardized. Neo-functionalists, including Haas, have then acknowledged the necessity of revising their work, in order to include the role of national leadership and leaders in the list of variables with influence in the process of European Integration ${ }^{65}$. After revising his work, Haas concluded that incrementalism in decision-making would prevail, unless it was disturbed by visionary using "high politics" 66 .

The need to reformulate the integration theory (particularly in what concerned the automaticity of the integration) was also admitted by Lindberg. The result was Europe's Would-Be Polity, a joint work with Stuart Scheingold. Here the authors analyze the EC as a political system, where inputs in the form of demands, support and leadership are transformed into outputs in the form of policies and decision. For them, the integration was a political process, in which coalition and leadership were seen as central aspects ${ }^{67}$ : "leadership has been available from to sources: the supranational institutions and the national governments. The Community's greatest successes have been scored when both were available to aid in the processing of demands"68. Yet, the national sources of political leadership identified by the revised neo-functionalism were not confirmed by the reality of the European integration during the 1970's. The European integration process appeared to have stagnated, and, as a consequence, scholarly interest in the EC faded.

62 Vid. LINDBERG, L., cited in LAURSEN, F., "Theory and Practice of Regional Integration", in Jean Monnet/Robert Schuman Paper Series, Vol. 8, n. ${ }^{\circ}$ 3. February 2008, p. 4.

$63 \mathrm{Vid}$. HAAS, E., cited in LAURSEN, F., op. cit., nota 62, p. 5.

${ }^{64}$ Namely the famous "empty-chair" crisis, followed be the Luxembourg compromise in January 1966 (which introduced the practice of unanimity).

65 Vid. DRAKE, H., op. cit., nota 57, p. 4; LAURSEN, F., op. cit., nota 62, p. 5.

${ }^{66}$ Ibid., p. 5.

67 Vid. LAURSEN, F., op. cit., nota 62, p. 5.

68 LINDBERG, L. and SCHEINGOLD, cited in DRAKE, H., op. cit., nota 57, p. 8. 
Also, an alternative view was starting to gain force. In a well know article, Stanley Hoffman maintained that the EC experience was better explained by the logic of diversity (therefore, opposed to the neo-functionalist logic of "automatic" integration) ${ }^{69}$. Also, he suggested that in key-areas for national interest, states would not be eager to choose the "insecurity" of the integration process over the safety, or the self-controlled uncertainty of the national independence. The tonic of Hoffmann's argument was thus mainly intergovernmental.

Things began to change in the 1980s, with the EC's new momentum associated with the completion of the Internal Market. The EC was increasingly enlarging its scope, developing new policies to complement early policies. The Commission under the Presidency of Jacques Delors contributed with leadership. Lindberg and Scheingold's revised neo-functionalist theory (written in the 1970s) appeared to fit perfectly to the developments of the 1980s. Plus, the academic interest on the European process gained a renewed urge: "the political leadership factor ... now seemed more relevant to understand the events than ever before, since a number of singular phenomena related to leadership were clearly present in the $1980 \mathrm{~s} " 70$. The more consensual view was that the integrative lurch of the EU in early 1990s was pushed by the technical and political expertise of Delors, and by the resourceful and determined statesmanship of both, Mitterrand and Kohl (the so-called "Paris-Bonn-Berlaymont axis" "11).

Some authors, however, emphasize more the national half of this leadership tandem. According to Mark Wallace, Helen Wallace, and C. Webb (1983) political leadership - in the form of a commitment based on national interests - by one or more EC members was a critical factor to successful policy-making in the $\mathrm{EU}^{72}$. Later, Andrew Moravcsik linked these interests to domestic political factors. Attention was therefore turned to national leadership, influenced and brought into being by domestic factors ${ }^{73}$. In fact, Moravcsik's Liberal Intergovernmentalism has become an important reference point for most studies on European integration. His framework includes three phases: national preference formation, interstate bargaining and institutional choice. With reference to the first phase, Moravcsik maintains

69 HOFFMANN, S., "Obstinate or Obsolete? The Fate of the Nation-State and the Case of Western Europe", in Daedalus 95 (Summer), 862-915.

70 Vid. DRAKE, H., op. cit., nota 57, p. 6.

71 DINAN, D., "The Commission and the IGCs", in NUGENT, N. (ed.), At the Heart of the Union: Studies of the European Commission, 2nd ed., ed. Macmillan Press, London, 2000, p. 262.

72 Vid. DRAKE, H., op. cit., nota 57, p. 8.

73 Ibid., p. 8. 
that economic interests dominate when national preferences of member states are formed. As for the bargaining phase, he argues that a state commitment in the negotiations (and interest in influencing the outcome) depends on what is at stake for that state. On the other hand, he downplays the role of Community actors (like the European Commission) in the negotiations. As regards the last phase (institutional choice) Moravcsik concludes that states choose to delegate or pool decision-making in international institutions mainly to get more credible commitments: "pooling and delegation is a rational strategy adopted by the member states to pre-commit governments to future decisions, to encourage future cooperation and to improve future implementation of agreements" 74 . To summarize, Liberal intergovernmentalists see the EU Member States "as unitary rational actors that are in control of the process of integration. In the big decisions the EU institutions do not play a very important role"75.

Moravcsik's propositions have been questioned by the Institutionalist approach, embodied by scholars with particular interest in the role played by European institutions ${ }^{76}$. Contrary to the Liberal Intergovernamentalism thesis, institutionalists assign a significant role to European institutions in day-to-day EU politics. Plus, some institutionalists go even further, contending that EU institutions could also have a say in major reforms (which occur through intergovernmental conferences). Derek Beach, for instance, has analysed the role of supranational institutions in the process of EU treaty reform (from the Single European Act to the Constitutional Treaty). He determined that in such negotiations, leadership is needed to overcome the high bargaining costs, and coordination problems. In fact, according to him "governments were not fully in control of the grand bargains on integration since the mid-1980s". And he goes on arguing that actually "bargaining costs in intergovernmental negotiation are often so high that most governments are forced to rely upon the expertise of the Council Secretariat and Commission for legal and substantive knowledge, and assisting in brokering deals"77.

A variety of other approaches and theories aimed at explaining the integration process or the EU governance system could have been analysed here. Arguably the fundamental conclusion would be the same. Different approaches emphasise different actors, types and resources of European

74 Vid. LAURSEN, F., op. cit., nota 62, p. 7.

75 Ibid., p. 9.

76 Such as Derek Beach, Jonas Tallberg, Thomas Christiansen, Desmond Dinan, Laura Cram, among many others.

77 BEACH, D., The Dynamics of European Integration: Why and When EU Institutions Matter, ed. Palgrave Macmillan, New York, 2005, p. 258. 
leadership. Despite this diversity, leadership potential is broadly available in the EU, allowing the Union to overcome most of its collective action problems ${ }^{78}$. In fact, as Finn Laursen maintains “...the EU is much better equipped with leadership possibilities than the other integration schemes. [However] ... it is risky business to rely solely on national leadership. It may be available and it may not"79.

When analysing leadership in the EU, particularly in what regards the historical decisions, one must acknowledge that national sources (especially from the big countries) have a significant weight. Some national political leaders, like Kohl, Mitterrand, Thatcher, and more recently, Merkel or Sarkozy, have played a determinant role in shaping both incremental and history-making developments of the EU (either pushing the process forward or backward). In fact, the Franco-German duo has assumed a leadership part on and off over the years; a "partnership" that some authors have labelled as a kind of "cooperative-hegemony ${ }^{80 "}$ ". Notwithstanding, the leadership role played by institutional actors, or by individual figures operating through institutional actors, should not be dismissed. For instance, the Commission was initially designed to take the initiative and act as an "honest broker" and, at least in day-to-day legislation, it still has the ability to perform these roles. In reality, as some scholars admit, part of the success of the EU is due "both to supranational institutions and the leadership they, especially the Commission, have been able to exercise" 81 .

\section{The quest for good leadership: the importance of ethics and effectiveness and how it applies to the $E U$ case}

Overall, as noted in section two, constructing the ultimate definition of leadership is not an easy task and probably it is not the most important one: "theorizing about leadership is great fun, hugely indulgent and largely useless" 82 . Perhaps the really meaningful question would be "what is good leadership", and particularly, "what is good leadership in the EU case"? In effect, leadership is frequently judged as being bad, good, or even non-existent (non-leadership). The quest, of course, is for "good" leadership. But, what is good leadership? As stated by Ciulla the word good here means two

${ }^{78}$ LAURSEN, F., "Institutions vs. Leadership: Towards a Theory of Credible Commitments", in Dalhousie EUSE Occasional Paper, n. ${ }^{\circ}$ 2, 2007, p. 18.

79 Ibid., p. 19.

80 PEDERSON, T., cited in LAURSEN, F., op. cit., nota 78, p. 11.

81 Vid. LAURSEN, F., op. cit., nota 78, p. 19.

82 Malaysian writer cited in GILL, R., op. cit., nota 3, p. 2. 
interrelated things: "morally good leadership and technically good leadership (i.e., effective at getting the job at-hand done)" 83 . The first issue is related to the ethical dimension of leadership. Put it simple, to become a leader is not enough to bring about change or being successful at doing something. It is also important to evaluate if that change is good for the group or for the organization, and to know what the leader's intentions were. In the literature on leadership, transforming or transformational leadership is closely connected with this ethical dimension of leadership ${ }^{84}$. In fact, Burns's theory of transforming leadership rests on a set of moral assumptions regarding the relationship between the leader and the follower. Contrasting it with transactional leadership ${ }^{85}$, Burns ${ }^{86}$ considers that transforming leadership occurs when "one or more persons engage with others in such a way that leaders and followers raise one another to higher levels of motivation and morality" [italics in the original]. And he goes on to argue that "At the highest stage of moral development persons are guided by nearly universal ethical principles of justice such as equality of human rights and respect for individual dignity. This stage sets the opportunity for rare and creative leadership" 87 . Therefore, the transforming leader fundamental act is "to induce people... to feel their true needs so strongly, to define their values so meaningfully, that they can be moved to purposeful action" 88 .

Transformational leadership theory has inspired several researchers. For example Bass (1985) has demonstrated that "empirically transactional and transformational leadership were two positively correlated dimensions" and that transformational leadership adds to transactional leadership in "generating positive outcomes in the groups and organizations led" 89 . Essentially, he makes the point that there is considerable evidence on the greater effectiveness of transformational leadership, for instance of political leaders or public officials ${ }^{90}$. Summing up, good leadership could be both effective and ethical, if the leader "successfully chooses the means that are the most likely to attain the ends sought, but also seeks to embody end-values ... and model-values ... in the process" $"$.

83 Vid. CIULLA, J., op. cit., nota 46, p. 308.

${ }^{84}$ Ibid., p. 316.

85 It must be said however that Burns agreed that transactional and transformational leadership were not necessarily opposite ends of a single dimension. Vid. BASS, B.M. with BASS, R., op. cit., nota 5, p. 619.

${ }^{86}$ Vid. BURNS, J.M., op. cit., nota 36, p. 20.

87 Ibid., p. 42.

88 Ibid., p. 44.

89 Vid. BASS, B.M. with BASS, R., op. cit., nota 5, p. 618; p. 648.

90 Ibid., p. 647.

91 Ibid., pp. 9-10. 
Which type of leadership is the most effective? Arguably, this is a question with no right answer. First, "adequate" leadership types and styles seem to vary according to the context. In fact, modern theories of leadership generally acknowledge the importance of the situation, denoting that the leaders' behaviour is systematically changed by changes in situational conditions. Second, there are an extensive list of types and styles of leadership. Bass, for instance, enumerates a plethora of diverse types and taxonomies, which include the democratic, autocratic, participative, group-developing, supportive, intellectual, expert, executive, bureaucrat, representative, among many more ${ }^{92}$. Here again, several scholars have observed that leadership types are normally classified according to the model of organization in which the leadership occurs ${ }^{93}$. So, instead of being a static phenomenon, leadership is characterized by evolutionary change and adaptability to the evolving nature of the organization: "as the organization matures, so will the strategies of its leadership change" 94 . Therefore, leadership is affected by the internal environment, i.e., the "organization's [or political entity] philosophy, size, structure, objectives, functions, complexity and institutional characteristics" 95 . The same could be said regarding the knowledge, skills and abilities that are off consequence to leadership. Specific situations call for specific competencies (in terms of task accomplishment and interpersonal relations ${ }^{96}$ of the leader. The leader's style should adapt to a given situation. Furthermore, the external environment is also likely to affect the organization and leader's behaviour. For example, the effect of crisis conditions is generally associated with the emergence of charismatic leadership. Clearly, as Bass puts it "effective leaders need to be alert and sensitive to circumstances which suggest that a problem exists" ${ }^{\prime 7}$. Political leaders must be able to read signals of dissatisfaction, of the seriousness of a problem, and of dangerous and opportunity of a crisis. They must be able to "diagnosis properly the conditions of a problem so that they can formulate appropriate policy responses" $" 98$. Also, typically, crises are associated with the demand for strong leadership.

Moving now to the question of leadership types, Bob Goudzwaard considers that there are two types of strong leadership worth distinguishing: responsive leadership, a type characterized primarily by responsiveness,

92 Vid. BASS, B.M. with BASS, R., op. cit., nota 5, pp. 29-45.

93 Ibid., p. 30.

94 Ibid., p. 727.

95 Ibid., p. 737.

96 On the word of Bass task accomplishment involves "traits like intelligence and knowledge" and interpersonal competence involves "the ability to communicate and to demonstrate, caring, insight, and empathy”. Vid. BASS, B.M. with BASS, R., op. cit., nota 5, p. 135.

97 Ibid., p. 113.

98 Ibid., p. 113. 
where the leader "shows profound awareness of existing problems and anticipates problems that are still emerging", and path breaking or innovative leadership, which is the "kind of leadership [that] demonstrates courage to break through the walls of apathy and/or suspicious" ${ }^{99}$. Roughly, this second type could be identified with charismatic and transformational leadership. In a fairly similar classification, Masciulli, Molchanov and Knight distinguish between adaptive leaders "who react and respond to challenges from local and global systems by introducing changes on the margins" and innovative leaders "who seek to implement more radical changes and revise the very rules of the game, or the nature of societal responses to the problem" 100 . According to them, innovative leaders often demonstrate exceptional or charismatic leadership.

As concerns leadership in international organizations, Building on Max Weber's classic scheme, Oran Young (1990) has identified three different forms of leadership that regularly have a role in the establishment of international institutions. According to him, there are four main types of leaders: structural, entrepreneurial, intellectual and charismatic. Drawing on Young's typology, Cramme singularizes three different types of leadership ${ }^{101}$. First, entrepreneurial or problem-solving leadership: in a negotiation context of informational asymmetries, high transaction costs, and contested agendas the leadership role is defined "by the ability to devise integrative solutions and package deals... [with] beneficial results for all actors involved". Second, structural leadership, when "actors in highly developed institutional settings shape processes and outcomes of negotiations positively because they are recognized as having a considerable comparative advantage [experience, knowledge, resources] over the others in a particular field". In this case, influence is a result of "natural authority", normally embodied by states and institutions (and not by individuals). Third, directional leadership, which relates to the "capacity of actor to produce enough social, political, or ... intellectual capital to make others change behavior or follow a particular idea in the pursuit of collective action". This will require inspirational figures.

Therefore, good leaders are characterized by their ability to understand the circumstances and the context they are living in, to define and implement a strategy, to bring about change whereas necessary, while preserving the core values of the group. Plus, these short/medium time measures should serve a long-term shared vision and purpose. This is a very harsh

${ }^{99}$ GOUDZWAARD, B., "The Need for Responsive Leadership”. Election Series'08, N. ${ }^{\circ} 2$, July 242008 , p. 1 .

100 Vid. MASCIULLI, J., MOLCHANOV M.A. and KNIGHT, W.A., op. cit., nota 21, p. 9.

101 Vid. CRAMME, O., op. cit., nota 12, p. 34. 
endeavour, especially in a complex polity like the EU, whereas leadership drives derive both from institutional and national sources. Also, the current troubled context furthers the challenges of exerting leadership in the EU. In the last decades, the polls show a remarkable decline in public support for the European project ${ }^{102}$. The era of "permissive consensus" has been replaced by a period of growing scepticism about and disapproving on the $\mathrm{EU}^{103}$. So, paradoxically, as Brussels multiplied the initiatives to enhance the Union's popular legitimacy, this popular legitimacy was dramatically declining, making the EU experience probably the lowest level of popular support in its history. How can this increasingly negative public opinion towards the EU be explained?

According to David Easton (1975) the analysis of political support is bi-dimensional: one dimension relates to modes of political support, and the other relates to objects of political support. On the former dimension, Easton differentiates between two modes of support: diffuse support, based on an ideological, sociological and cultural attachment (i.e., it represents a general evaluation of "what the object is or represents"); and specific support, based on rational calculations of material costs and benefits (i.e., relates to concrete policy outcomes or the performance of a polity, therefore being policy oriented). On the latter dimension, Easton differentiates three different objects: the community, the regime, and the authority.

Adapting Easton's framework, Lindberg and Scheingold identified two main types of support for a political system that could be used to analyze the European case: affective support, based on a "diffuse and perhaps emotional response to some vague ideals embodied in the notion of European unity" 104 ; and utilitarian support, based on rational calculations of material costs and benefits of membership in the EU. These two types of support are really two faces of the same coin, since they are not mutually exclusive. The first provides a "basic reservoir of good will towards a political system", while the second one "determines whether this basic reservoir of support goes up and down"105. Hence, if a citizen considers that he benefits from a political system, his underlying level of support will grow accord-

102 As stated by the Euroborameter opinion polls, in the late 1980s over 70 per cent of the citizens supported their country's membership of the EU, while in the last decade roughly 50 percent had the same opinion. Vid. HIX, S., What's Wrong with the European Union and How to Fix It, ed. Polity Press, Cambridge 2008, p. 52.

103 BOOMGAARDEN, H.G., SCHUCK, A.R.T., ELENBAAS, M. and VREESE C.H., "Mapping EU attitudes: Conceptual and empirical dimensions of Euroscepticism and EU support”, in European Union Politics, 12(2), 2011, p. 242.

104 LINDBERG, L.N. and SCHEINGOLD, S.A. Vid. BOOMGAARDEN, H.G., SCHUCK, A.R.T., ELENBAAS, M. and VREESE, C.H., op. cit., nota 103, p. 244.

105 Vid. HIX, S., op. cit., nota 102, p. 58. 
ingly, while if he perceives that he loses, his underlying level of support will diminish. For Simon Hix it is mainly a mathematical calculus ${ }^{106}$, in which citizens who perceive they gain from integration process tend to support the EU, and those who perceive that integration process threatens their interests tend to oppose the EU.

While a utilitarian assessment could be an important tool to explain variations in attitudes towards the EU, arguably it undervalues a crucial dimension: leadership. European leaders could have an important role in changing citizen' underlying levels of support for the EU. In the absence of a European demos, the affective support for the EU will probably be lower than the ideal. Also it is understandable that in times of difficulties, such as the present economic and financial crisis, the utilitarian support (based on the policy outcome) is dangerously low. In such a challenging period, European leadership becomes more vital for the success of the EU. How leaders respond to hopes and concerns of the population, how they engage with citizens and how adequately and timely they handle the euro crisis are crucial to facilitate the sense of belonging and, ultimately, to promote the union (or disintegration) of the European project.

\section{Assessing EU leadership in the euro crisis: pragmatic, directional, or both?}

\section{The context: the need for reform}

In 2008 a financial crisis erupted in the United States, undermining many of the largest financial institutions of the country. The crisis rapidly spread to the rest of the world, provoking serious damages to a large part of the global financial system. Europe was no exception. According to the World Bank ${ }^{107}$, the region has been hit by a crisis on multiple fronts, since countries are facing major external macro-financial shocks. Specifically, global growth has slowed down, resulting in falling export market demand. Also, major banks and other financial institutions in developed countries have markedly reduced the availability, and increased the cost of external finance across public and private sectors.

106 Ibid., p. 64.

107 WORLD BANK, "The crisis hits home: Stress-testing Households in Europe and Central Asia", 2010. Accessed at http://siteresources.worldbank.org/ECAEXT/ Resources/258598-1256842123621/6525333-1259681048367/WorldBank_Crisis_Report.pdf (22.05.2012). 
The economic crisis and particularly the so-called sovereign debt crisis that dramatically hit some of the Eurozone states rendered obvious that, at least in the economic governance area, the EU needed reform. The struggling of Greece, Ireland and Portugal, and the menace pending over other euro economies, including the big Spain and Italy, brought to day light the fragilities of the EMU. Confronted with the crisis' escalate, the European leaders came to agree on the necessity of reforming some of the dispositions of the (still new) Lisbon Treaty ${ }^{108}$, in order to accommodate new rescue mechanisms and also to enforce tougher supervision rules and stricter budget discipline in the Euro zone. The urgency of the measures was stressed by the constant "pressure" of the financial markets. The announced purpose was then to strength the economic pillar of the EMU and to complete a truly fiscal union.

Nevertheless, the EU's managing of the so-called economic and financial crisis has been anything but an easy mission, particularly since European leaders are not fully in control off the process. For one part, there are external variables such as the constant pressure exerted by the rating agencies over the more fragile EU's economies. Plus, the Euro crisis is part of a wider "systemic crisis" 109 , which implies a "domino effect" that could not be prevented, unless coordinated measures for reforming the world's financial system were agreed. As concerns the internal environment, the difficulties of reaching a consensus in an enlarged and heterogeneous Union have hampered a timely crisis' management. The EU is a political system in the making, which probably only succeed if vested interest is overcome by collective goals. However, the rise of euroscepticism accentuated by the current economic and financial instability has dramatically conditioned the speeches and the attitudes of the national leaders towards Europe; even those who were traditionally pro-European have become obsessed with short-term gains at the expenses of mutual appreciation. In fact, national

108 According to Broin "Two existing treaty provisions in particular - the "no bailout clause' (a ban on a euro area state paying another's debts) and the 'prohibition on monetary financing' (a ban on the European Central Bank or national central banks financing governments) - were considered as legal impediments to deploying key crisis resolution measures such as the European Financial Stability Facility (EFSF)". BROIN, P.O., "The Euro Crisis: The Fiscal Treaty - An Initial Analysis". Institute of International and European Affairs, Working Paper 5, 2012, p. 2.

109 According to S. CLAESSENS, D. KLINGEBIEL and L. LAEVENS a "systemic crisis is a situation here an economy faces large-scale banking and corporate distress ... A systemic crisis involves complicated coordination problems". Vid. CLAESSENS, S., KLINGEBIEL, D. and LAEVEN, L., "Resolving Financial Systemic Crises: Policies and Institutions", World Bank Policy Research Working Paper 3377, August 2004. Accessed at http://wwwwds.worldbank.org/external/default/WDSContentServer/WDSP/IB/2004/09/07/000160016_2 0040907154538/additional/126526322_20041117165058.pdf (22.05.2012). 
leaders turn out to be "less and less capable of making concessions, let alone personal sacrifices, for the "common European good"" 110 . Some member-states' positions during this process illustrate well these feelings. Particularly, all the controversy surrounding the "fiscal compact Treaty"111 highlights many of the dilemmas discussed in the precedents sections.

In brief, the seriousness of the situation urged the European leaders to take action, disclosing a window of opportunity to reform the procedures and institutions of the euro governance. Whether being willing to do the reform or being pushed to it, the fact is that the European leaders took the opportunity. European leadership during this process illustrated nonetheless a rather "schizophrenic" situation. Due to its economic performance and dimension (in terms of population), Germany emerged naturally in a leadership position to tackle the crisis; it may even been said that Europeans start to call for German leadership. But, at the same time Europe was not willing to accept German's authoritative leadership style.

\section{The pragmatic dimension of leadership: strategy and measures for tackling the crisis in the short/medium term}

In the traditional "State of the Union" address to the European Parliament, the Commission President, José Manuel Durão Barroso, has referred to political leadership as a way of "making possible what is necessary"112 [our translation]. This is a simple but an accurate assertion, which reflects the need for pragmatic leadership. Since the crisis erupts in 2008, a wide backdrop of measures have been decided at the European level to handle the crisis, the most famous being the establishment of a temporary fund - the European Financial Stability Facility (EFSF) - along with a permanent fund - the European Stability Mechanism (ESM) - that should enter into force in July 2012. However, other important decisions were taken "including liquidity measures by the European Central Bank, legislative re-

110 Vid. CRAMME, O., op. cit., nota 12, p. 46.

111 The Treaty on Stability, Coordination and Governance in the Economic and Monetary Union (also known as Fiscal Compact Treaty or Pact) was signed on 2 March, 2012 by 25 out of 27 EU Member States, and is expected to enter into force in January 2013 (provided that twelve Eurozone Members Sates have deposited their instrument of ratification, or on the first day of the month following of the deposit of the twelfth instrument of ratification, whichever is the earlier).

112 "Et le leadership politique c'est cela, rendre possible ce qui est nécessarie" (in the original). BARROSO, J.M.D., "European Renewal: State of the Union Address 2011". Speech 11/607. Accessed at http://europa.eu/rapid/pressReleasesAction. do? reference=SPEECH/11/607 (20.10.2011). 
form of financial markets passed by the European Parliament and the Council, and the establishment of a loan pool to channel emergency funding to euro area states in conjunction with aid from the International Monetary Fund" 113 . Greece, Ireland and afterwards Portugal benefit from this bailout mechanism, but as a consequence, they were put under severe austerity programs. The Commission alongside the European Central Bank and the International Monetary Fund (the so-called "troika") were put in charge of modeling and monitoring the correct implementation of the "rescue programs" in Greece, Ireland and Portugal. Plus, the vertiginous escalate of the crisis lead to the resignation of the elected governments in Italy and Greece. The politicians were substituted by "technocrats", which were considered more skilled for putting the countries' finances in the right track ${ }^{114}$. The main argument here was that "technocrats" have a reputation of competence and experience: "a reputational advantage both in terms of knowledge and a sense of putting national interests above party political interests"115. Therefore, they would be perceived by the financial markets as being capable of implementing the required reforms, regardless the toughness of the measures needed; measures that most likely would fail to get the necessary political support if introduced by politicians. However, the criticisms were immediate. For one part, these "substitutions" risk to diminish popular legitimacy in the EU, since they were not subjected to democratic approval. In fact, for some analysts the process represented a sort of "democratic pause", meaning that these governments lack the fundamental political legitimacy that only elected party politicians can bring to a government. Thus, these are necessarily short-time solutions that need to be integrated in a wider and longer-term plan endorsed by the European citizens.

Germany, backed essentially by France, has apparently taken the lead in grasping a strategy to thwart the crisis. But the plan's resemblance with German's fiscal model (based on sharp reduction of budget expenditures in order to control the deficit, and a strict application of the Stability and Growth Pact) contributed to yield an image of a directoire on the European citizens eyes: "When the crisis burst, the Franco-German directoire decided to work as an emergency government" 116 . The media coverage also conveys

113 Vid. BROIN, P. O., op. cit., nota 108, p. 1.

114 After standing aside, Italian Prime-minister Silvio Berlusconi and Greek Prime-minister George Papandreou were succeeded respectively by Mario Monti (a former Commissioner) and Lucas Papademos (a former vice-president of the European Central Bank).

115 FEATHERSTONE, K., cited in BBC NEWS Magazine " Who, What, Why: What tecnhocrats achieve that politicians can't?, 2011. Accessed at http://www.bbc.co.uk/news/ magazine-15720438 (10.04.2012).

116 MONTANI, G., "After the fiscal compact, Europe democracy", 2012. Accessed at http://www.euractiv.com/future-eu/fiscal-compact-european-democracy-analysis-510751 
and even accentuates this image. Actually, the European press abundantly stressed the "unloved" (and apparently undesired) German leadership. Plus, the announced aim of creating a European culture of stability whatever the "price" to be paid by the citizens, further damage the already fragile European public support. Thus, a considerably weaker popular legitimacy was one of the "collateral damages" resulting from Franco-German's recipe to save the Eurozone. This scenario was aggravated by the above-mentioned accusations of German "hegemony", translated in an allegedly desire of Chancellor Merkel to force the other member states to adopt the structural reforms that she deemed necessary.

Despite all the doubts about the success of a plan that is based essentially on austerity (with almost no reference to growth measures), during this crisis European leadership is being exerted - at least in what concerns its pragmatic dimension - and has produced several changes which would be inconceivable a few years ago. Yet, the resource to bilateral negotiations, and the image of Franco-German's plan presented to the other EU's members as an "accomplished fact" create justifiable doubts about the unity of the European leaders; even though the final decisions were for the most part taken in appropriate forums, such as the European Council and the Eurozone summits. Plus, Franco-German proposed solutions have failed to win the citizens' hearts and minds. By focusing on reorienting national economies towards sufficiency and sustainability, they were unable of envisioning and convey a shared (and optimistic) idea for the future of a hopefully strengthened political Union.

\section{The directional dimension: a design and an integrated vision for the long-time}

During the first years of the crisis the European's "recipe" for the crisis appeared to spin around bail-out mechanisms. EU leadership was essentially reactive to markets" "moods". In the mid-2011 this tendency started to reverse, as the debate on a reinforced fiscal union to underpin the euro become the main topic of the Franco-German agenda. A majority of European leaders begin to agree on the necessity of reform the Eurozone governance to enshrine stricter budget policies and closer economic policy coordination. Chancellor Merkel, in particular, insisted on amending the EU treaties, but British Prime-Minister, David Cameron, strongly opposed the idea. Consequently, on the December 2011, twenty-five Europeans lead- 
ers adopted a new fiscal treaty ${ }^{117}$, that sits alongside the other EU treaties. The text, thus, has the bizarre classification of a strictly "intergovernmental treaty", even though its implementation involves using the EU institutions.

The so-called fiscal Treaty focus on three main issues: fiscal stability, that is the rules on the levels of government deficit and government debt; economic co-ordination in the EU; and governance of the Euro zone. In the first domain, the new document establishes a limit for the annual structural deficit, which should not exceed $0.5 \%$ of Gross Domestic Product. If significant deviations for this goal occur, a correction mechanism will be trigger automatically (including the obligation for the deviant state to correct the situation within a defined period of time). As for coordination, the participating Member States agree to take the necessary actions and measures in all the domains, which are essential to the good functioning of the euro area in pursuit of the objectives of fostering competitiveness, promoting employment, contributing further to the sustainability of public finances and reinforcing financial stability. Finally, in what regards the Eurozone governance, the treaty institutionalizes the Euro Summit (a meeting of the heads of state and/or government of euro area countries, plus the President of the Commission), which will take place at least once a year. The Euro summit will elect a president at the same time as the election of the president of the European Council.

It is too soon to predict the real impact of the new fiscal treaty in tackling the euro crisis. In actual fact, the new document (still in the process of ratification) has been subject to a wide range of criticisms, the major concern being whether it will produce the desired effect. For one part, as mentioned, in its present form, the treaty is not part of the EU law. Consequently, to a large extent it depends on EU primary law. Also, some of the provisions are considered excessively vague. As far as the participation of the European institutions in the Economic governance, even though the new fiscal treaty secures an important role for the Commission in the Eurozone governance, it sidelines the institution in the bail-out mechanism which will be strictly intergovernmental ${ }^{118}$. The apparent decline of the European Commission's role is, in fact, the main danger of the present European integration's path. As J.M. Simon stresses "The new treaty will use the European Commission and the European Court of Justice to enforce the rules but the

117 The Treaty on Stability, Coordination and Governance in the Economic and Monetary Union was then formally signed on 02 March 2012 by twenty-five out of the twenty-seven member states of the European Union.

118 Vid. MONTANI, G., "After the fiscal compact, Europe democracy", 2012. Accessed at http://www.euractiv.com/future-eu/fiscal-compact-european-democracy-analysis-510751 (23.04.2012). 
European Commission has seen its powers removed like never before and has de-facto become a secretariat of the European Council"119. Furthermore, the new treaty does not fulfil the vital necessity of a European growth plan. Still, as Carol Ulmer observes, the treaty should be seen as a first step in the convergence path, "which must be greatly improved" 120 .

The European leadership has been able to take the first pace in order to correct some of the weakness of the EMU. Even though many criticisms highlight what remains to be done in terms of an effective structural reform, the Franco-German duo was able to put in motion a plan for adapting the EU economic governance, which arguably would contribute to strengthen the fiscal union. Yet, European leadership has failed to integrate this plan to reform institutions and policies (mainly in the economic governance area) in a wider long-term vision for a more political and cohesive European Union. After the new fiscal pact was signed, Chancellor Merkel did unveiled what could be considered a proposal for a stronger and integrated Europe:

"My vision is political union, because Europe has to follow its own path. We need to get closer step by step, in all policy areas ... In the course of a long process; we will transfer more powers to the Commission, which will then work as a European government for European competencies. This implies a strong Parliament. The Council, which brings together heads of governments, will form the second chamber. Finally, we have the European Court of Justice as the Supreme Court. This could be the future shape of the European political union in a while and, as I said, after many steps"121.

Although there is still a difference between a declaration of intentions and a real strategy to implement it, Merkel's outlined institutional reform would potentially contribute for a more integrated political Union. Particularly, the emphasis on the necessity to reinforce the roles played by the Commission and the Parliament would be a step towards a federal model for Europe. However, arguably this proposal has a fundamental flaw: it was presented as Chancellor Merkel's vision for Europe, whereas it should be a shared European vision.

119 SIMON, J.M., "The new fiscal pact: the medicine that may end killing the patient", 2012. Accessed at http://www.euractiv.com/euro-finance/new-fiscal-pact-medicine-maykilling-patient-analysis-510521 (21.02.2012).

120 ULMER, C., “A useful treaty or an empty gesture?", 2012. Accessed at http://www. euractiv.com/euro-finance/useful-treaty-empty-gesture-analysis-510612 (23.04.2012).

121 MERKEL, A., cited in MONTANI, G., "After the fiscal compact, Europe democracy", 2012. Accessed at http://www.euractiv.com/future-eu/fiscal-compact-europeandemocracy-analysis-510751 (23.04.2012). 
Arguably, the problem with today's European leadership is essentially related with the absence of a cohesive vision for the long-term. Applying Cramme's typology of three types of leadership (problem-solving, structural and directional) to the EU case is possible to conclude that the first two types of leadership are generally present. In particular, the role of institutional actors (for example, the European Commission, the Council Secretariat or the EU Presidencies) and of some individual figures (like the President of the European Commission and some national leaders) during crucial negotiations is widely recognized in the literature on the $\mathrm{EU}^{122}$. However, the contemporary EU appears to lack essential directional leadership. As noted above, this type of leadership would require inspirational figures, but few, if any, of the current European leaders have succeeded in inspiring and grasping the hopes of EU's citizens, especially in what concerns a plan for the future of the European project. Effectively, over the past years, inspirational figures (at least in a position of authority) are precisely what appears to be missing in Europe ${ }^{123}$. Thus, the lack of "intellectual capital" is one of the problems with EU leadership ${ }^{124}$.

\section{The Franco-German tandem: a new balance of power or a matter of perception?}

Even though it is still too soon for evaluating the efficacy of the adopted measures to settle the crisis, one could risk an assessment of the leadership exert by the Franco-German tandem during this process. In effect, at least in the eyes of the public opinion, German and France have assumed a leading role in tackling the euro crisis. Some of the measures agreed, stipulating more rigor in the public finances and a bolstering of the control mechanisms, were probably inevitable. In particular, the necessity to reform the

122 This is for example the case of some of the most decisive steps of EU treaty reform negotiations. On the role of the institutional actors on EU treaty reform negotiations, see for example, BEACH, D. and MAZZUCELLI, C. (eds.), Leadership in the Big Bangs of European Integration, ed. Palgrave, New York 2007; CHRISTIANSEN, T., "The Role of Supranational Actors in EU Treaty Reform", in Journal of European Public Policy, 9:1 February 2002, pp. 33-53; CHRISTIANSEN, T.; FALKNER, G. and JORGENSEN, K.E., "Theorizing EU Treaty Reform: Beyond Diplomacy and Bargaining”, in Journal of European Public Policy, 9:1, February 2002, pp. 12-32; DINAN, D., "The Commission and the IGC's", in NUGENT, N. (ed.), At the Heart of the Union: Studies of the European Commission, $2^{\text {nd }}$ ed., ed. Macmillan Press, London 2000; GRAY, M. and SPENCE, D., "The Commission and Intergovernmental Conferences", in SPENCE, D. and WITH EDWARDS, G. (eds.), The European Commission, $3^{\text {rd }}$ ed., ed. John Harper Publishing, London 2006.

123 Vid. CRAMME, O., op. cit., nota 12, p. 46.

${ }^{124}$ Ibid., p. 46. 
governance of the Eurozone was evident. The same could be said regarding the establishment of renewed "rescuing" mechanisms designed to help states with less robust economies.

But Merkel and Sarkozy were not successful in passing the message: neither in what concerns the adequacy of the reform accorded, nor in establishing that the measures adopted were not to blame for the escalate of the crisis. Also they were unable to secure a full European consensus. This normally requires a figure capable of exerting a communicator/mediator role, a part many times efficiently performed by the European Commission. However, in the present Euro crisis' managing the Commission was apparently assigned a marginal role. The majority of the adopted solutions resembled a "minimum common denominator", and still some member states opted out (as was the case of the new fiscal treaty ${ }^{125}$ ). Consequently, the negative image of a directoire prevailed, endangering the solidarity and cohesion of the European project and jeopardizing the European citizen's support.

In fact, the criticisms highlighted by the media regarding Franco-German "monopoly" of leadership appear to be endorsed by many EU specialists. Some go even further making the case that the euro crisis has been changing the balance of power in Europe, leading to a German "hegemony". For Charles Grant, Germany is emerging as the "unquestioned leader" pushing France for a "subordinate role"126. That being said, we must stress that the Franco-German influence in the integration process could hardly be considered a novelty. As referred to in precedent sections, more than once in the history of European Union's construction, the Franco-German axis had become decisive to push the integration process forward. This was for example the case of the reforms that lead to the completion of the single market, and afterwards the creation of the European Monetary Union and the political union.

But when comparing today's Europe with Europe in the late eighties and early nineties there are, indeed, two differences worth noticing: first, back then the Commission, under the Presidency of Jacques Delors, was an extremely influent player; second, even though Helmut Kohl and François Mitterrand had pivotal roles in pushing the integration process forward, the crucial decisions were a result of an enlarged negotiating process. In today's EU the negotiation dimension is still present. This fact is proved by the UK's refusal to resume the European treaty reform process, which pushed the new agreement to the odd position of an "exclusively intergovernmental treaty", existing outside of the EU treaties framework; and afterwards, by the decision of UK and Czech Republic not to sign the new fiscal com-

125 The "fiscal compact" was not signed by the United Kingdom and Czech Republic.

126 GRANT, C., "Monnet loses to de Gaulle", 2011. Accessed at http://www.cer.org.uk/ publications/archive/bulletin-article/2011/monnet-loses-de-gaulle (12.01.2012). 
pact. In effect, the intransigency of the UK position, seconded by the Czech Republic, should at least cast some doubts in the perceived Franco-German "domination" over their partners.

Notwithstanding, it is also undeniable that there has been a dramatic alteration in the perception of the European citizens regarding the process of salient decision-making in the EU. Indeed, the key decisions on the euro crisis were sensed as being taken mainly by two major players from two big countries - Chancellor Angela Merkel with the help of President Nicolas Sarkozy - and then endorsed by the other euro leaders. Paradoxically, the perceived strong leadership performed by both actors - normally a welcomed characteristic in times of crises - seems like to have become counterproductive in the EU case. At least, it has contributed for broadening the decline of popular legitimacy in the EU, since a significant percentage of the European citizens appear to question the authority of the two perceived major decision-makers. By apparently subverting one of the basic principles of the EU - equality between big and small member states - Europe's response to the present euro crisis looks to have furthered the gap between small and poor and big and rich states ${ }^{127}$.

Furthermore, the Commission was somewhat left on the margins of the process. In line with this reasoning, Olaf Cramme, referring to the current European policy-making process, sharply observes:

"Whereas the Commission used to be the central mechanism for reducing the transaction cost of any contested bargain between member states, it has become almost powerless in the face of a shifting political agenda which is now dominated by greatly sensitive policy issues outside of classical community business" 128 .

In fact, unlike other regional integration experiences, the European integration process has given "supranational" powers to common institutions. The Commission, in particular, was assigned with significant leadership potential. However, as the Commission performed this role successfully, some national leaders start to felt that the institution was becoming to powerful and opportunistic in pursuing its own agenda; one that was visibly more integrationist than the agenda envisioned by those national leaders. Consequently, the European Council (for some a vehicle for collective national leadership) was created. Plus, other forms of national leadership were added to the process, gradually sidelining the Commission's role. The "golden

127 Ibid.

128 CRAMME, O., "What Leadership Crisis in the EU?", 2011. Accessed at http://www. policy-network.net/articles/4020/What-leadership-crisis-in-the-EU (21.02.2012). 
age" of the Commission is identified with Delors' presidencies. After this period, the Commission has adopted a much more "low-profile" style, to say the least. Notwithstanding, it did manage to become associated to the decisive steps of the EU construction. The present euro crisis represents no exception. The Commission, with the European Central Bank and the International Monetary Fund formed the so-called "troika" responsible for defining and monitoring the correct implementation of the rescuing Programs in Greece, Ireland and Portugal. Also, the Commission President, Durão Barroso, has come up with several proposals based on a "twin track approach on stability and growth" 129 . The European Commission's President has insisted for instance in the necessity to complement "austerity measures" with a structured plan for growth and employment ${ }^{130}$.

Yet, despite the Commission's initiatives, it is obvious that in this particular crisis the major inputs in terms of leadership are national. The recent presidential elections in France, and the consequent stepping aside of Sarkozy, succeeded by François Hollande, does not appear to change the importance of national leadership in this crisis' management. However, Hollande's unveiled proposals for settle the crisis, do cast some doubts about the continuity of the Franco-German axis' harmony.

\section{Concluding remarks: European leadership beyond the Euro crisis}

Leadership and the determination of who is to lead a group has always been a pivotal question ${ }^{131}$. As the societies grew in size and complexity, so the qualities of the leader change. In multi-level political systems, such as the European Union, leadership is more diffuse and therefore more difficult to grasp. The specificities of a multi-level arrangement render personality politics extremely difficult. Plus, in modern times, individual leaders have lost some of their importance. And yet, “... leaders are as necessary today as ever" 132 . In fact, timely political leadership and adequate leaders could

129 BARROSO, J.M.D., "Seizing the moment to boost growth: 9th May message from the European Commission", Speech/12/337, 08 May 2012. Accessed at http://europa.eu/ $\mathrm{rapid} / \mathrm{pressReleases} A c t i o n . d o$ ?reference=SPEECH/12/337 (25.05.2012).

${ }_{130}$ On November 2011 the European Commission adopted a package enabling "new action for growth, governance and stability". The adopted package contains four elements: the 2012 Annual Growth Survey setting out the economic priorities for the coming year; two Regulations to tighten economic and budgetary surveillance in the euro area; and a Green Paper on Stability Bonds.

131 JACOBSOHN, J.A., An Introduction to Political Science, ed. West/Wadsworth, Belmont CA 1998, p. 167.

132 Ibid., p. 171. 
have a tremendous impact on the success or failure of an organization or a political entity.

Such reasoning is even more relevant in times of crisis, like the present economic and financial one. The inadequacy of the existing Eurozone mechanisms to cope with a systemic crisis highlighted the necessity of reforming the EU economic governance. A first set of reforms was designed. In effect, in the past two years European leaders have adopted several measures to cope with the crisis. The short-term ones are already being implemented, but others, like the new fiscal treaty, are still in the process of ratification. Whether the plan designed to tackle the crisis will be effective remains to be seen. Yet, the growing disillusion of the European citizens regarding the path of the European project shows that proper political leadership should also rest on a vision for the future, one that reflects the European citizens' expectations and demands. An effective European leadership, thus, is one that is capable of complementing pragmatism with direction.

Despite several verdicts of failure, the European project has reached an impressive degree of integration ${ }^{133}$, which should not be jeopardized by strictly intergovernmental logics. A multi-level political system like the EU would benefit from a truly "shared leadership" that embraces national actors alongside institutional ones. It is well known that in times of difficulties or stalemates, the integration process has been traditionally impelled forward by the dynamism of a core group, some times against the will or the inertia of the others. From the normative perspective, there is nothing wrong with the ideal of shared leadership. Actually, "rather than a aria, leadership can be a chorus of diverse voices", as long as these voices will be "singing in unison" 134 [my emphasis]. Instead of being a negative feature, this almost obligation to rest in leadership "partnerships" may constitute one of the keys for the success of the European integration. Accordingly, the FrancoGerman tandem (preferably in concert with the European institutions, such as the European Commission, and the EP) could be beneficial for Europe, if and when it envisions a viable and shared solution for Europe as a whole. The EU is still a common project. Thus, as Durão Barroso asserts, the answer to our problems could only be European ${ }^{135}$.

133 According to Hix the EU is "one of the most remarkable political achievements of the modern age". Vid. HIX, S., op. cit., nota 102, p. 26.

134 PASTERNACK, B., WILLIAMS, T.D. and ANDERSON, P.F. Vid. GILL, R., op. cit., nota 3 , p. 31 .

135 BARROSO, J.M.D., "European Renewal: State of the Union Address 2011”. Speech 11/607. Accessed at http://europa.eu/rapid/pressReleasesAction.do?reference=SPEECH/11/607 (20.10.2011). 